\title{
Development of Guided Inquiry-Based Worksheet as Teaching Materials on Elements, Compounds, and Periodic Table
}

\author{
Rahmi Mudia Alti \\ ${ }^{1}$ Aircraft Electrical Department, Faculty of Engineering, Universitas Nurtanio, Jl. Pajajaran \\ No. 219, Lanud Husein S., Bandung, Indonesia \\ E-mail: rahmimudia68@gmail.com
}

Received: 14 June 2021; Accepted: 22 June 2021; Published: 30 June 2021

\begin{abstract}
The chemistry lecture at Universitas Nurtanio needs teaching materials innovation to increase students' activity and learning motivation. This research aims to develop worksheets on the material of elements, compounds, and the periodic table and determine the validity and practicality. The stages carried out in this study are the define, design, and development stages. The validity and practicality data analysis used the moment kappa $(\mathrm{k})$ formula. The average validity and practicality are 0.87 and 0.77 , respectively, with very high criteria. The validity and practical result indicate that a guided inquiry-based worksheet can be applied as teaching materials on elements, compounds, and the periodic table in lectures.
\end{abstract}

Keywords: elements, compounds, guided inquiry worksheet, periodic table, teaching materials

DOI: http://doi.org/10.15575/jtk.v6i1.10377

\section{Introduction}

One of the reasons for the low quality of education in Indonesia due to the learning process is because it's still too oriented towards mastering theory and memorization (Mustikasari et al., 2020). Instead, curriculum development for conceptual aspects requires active learning that prioritizes personal experience through observation, asking questions, making associations, concluding, and communicating (Depdiknas, 2008; Kemdikbud, 2013).

Based on the results of observations in the lecture process at Nurtanio University, it can be seen that, in general, student learning characteristics in chemistry lectures are as follows: 1). Students still have difficulty understanding the concepts they are learning if they are not involved in building conceptual understanding; 2). Students tend to memorize without exploring the substance of the material being studied; 3 ). Students who listen and respond to the lecturer's presentation are only students who have more abilities; 4). Students have low reading interest.

Chemistry lecture is a compulsory subject for first-year students. With this lecture, students are expected to have the correct basic concepts of chemistry to be applied in everyday life and support them in the world of work later. In carrying out the chemistry lecture process, lecturers use basic chemistry textbooks from various publishers and authors. The material was delivered using lecture methods and group discussions with the help of whiteboards, markers, and projectors. The essence of the lecture material is usually presented on the whiteboard, and at the end of the lecture, students are welcome 
to ask questions or the lecturer holds a quiz related to the material being taught.

From the results of the implementation of the lectures as described above, conclusions can be drawn regarding the low motivation, understanding and learning outcomes of chemistry. The motivation is seen from the sluggishness of attending lectures, the inability to answer questions from the lecturer, and the low value of learning outcomes evaluation.

Based on this, innovation in teaching materials is needed in lectures. These teaching materials can be used to support the use of textbooks by lecturers so far. One form of teaching materials is worksheet, an activity sheet that guides the student in finding concepts and completing assignments to achieve competence (Ningsih, 2019). Worksheet function is a medium for students to understand the concept with the help of some questions that lead to the formation of concepts. The developed worksheet is expected to increase student involvement in lectures. This is the reason why guided inquirybased worksheets were developed.

The existence of teaching materials in the form of guided inquiry-based worksheets is not intended to eliminate textbooks that have been used so far but to support and streamline their use (Arsanti, M., 2018). Guided inquirybased teaching materials in the form of worksheets are important to be developed at the university level because they provide models, information, and key questions that can lead students to understand chemical concepts, especially on elements, compounds, and the periodic table.

With teaching materials in the form of worksheets based on the guided inquiry learning cycle, students will learn well and develop process skills in lectures with teaching materials in worksheets based on the guided inquiry learning cycle. This is because the guided inquiry is built on the idea that most students learn best when they are actively involved in analyzing models, discussing ideas, working together in groups to understand concepts, solving problems, reflect on what they have learned, and interacting with teachers who serve as facilitators in the learning process (Hanson, 2006).

Research conducted by Aulia et al. (2018) that guided inquiry-based teaching materials are effectively used in learning the concept of solubility and solubility product (Ksp) as evidenced by an increase in $\mathrm{N}$-gain scores in the medium and high categories. Furthermore, guided inquiry teaching materials help think carefully, analyze, design various practical topics, and reflect on them (Pamenan et al., 2019). In addition, learning with the guided inquiry model with student woksheets can significantly improve learning outcomes in the experimental class (Amalina \& Wardani, 2018). Therefore, the authors are interested in developing teaching materials in the form of a Guided Inquiry-based worksheet on the material "Elements, Compounds, and the Periodic Table."

\section{Research Method}

Based on the research objective, namely developing and producing teaching materials in the form of guided inquiry-based worksheets on the material "Elements, Compounds, and the Periodic Table", the type of research used is Research and Development $(R \& D)$. Therefore, the stages in this study consist of the define, design, and development stages with the following explanation:

\subsection{Define Stage}

This stage is conducted to determine conditions related to the chemisty lecture process (Hartono \& Noto, 2017), analyze the problem by analyzing lecture objectives, analyze student abilities, and identify the main concepts in the material elements, compound and the periodic table.

Then the concept analysis was conducted. Concept analysis is the identification of the main concepts in the material to be discussed. The main concepts identified include protons, electrons, neutrons, cathode rays, Rutherford 
experiment, Thomson experiment, Millikan experiment, element, atomic number, mass number, period, group, metal, non-metal, metalloid, compound, cation, anion, major metals, transition metals, conservation of mass, fixed ratios, multiples of ratios, conductors, insulators, semiconductors, alpha particles, ionic compounds, covalent compounds, $x$ rays, Lewis structures, the nomenclature of compounds, orbitals, isotopes, valence electrons, hydrates, and octets.

Analysis of learning objectives is the stage of converting task analysis and concept analysis into learning objectives. This analysis is used as the basis for constructing the developed teaching materials. The objectives of the lecture are as follows: 1 ). Describe the process of discovering subatomic particles; 2). Explain the basic laws of chemistry; 3 ). Understand and apply the mole concept; 4). Understand unit conversions and the metric system; 5). Able to determine the atomic number and mass number; 6). Understand the concepts of anions and cations; 7). Understand electron configuration and the periodic table; 8). Understand the classification of elements in the periodic table, 9). Distinguish between metallic, non-metallic and metalloid elements; 10). Understand compound nomenclature.

\subsection{Design Stage}

Design of teaching materials in the form of worksheets performed by selecting a format following the guided inquiry learning cycle, designing and finding models that follow the objectives of the lecture to be achieved. Next, determine the subject matter's title developed in the guided inquiry teaching materials in the form of a worksheet on the elements, compounds and the periodic table material. This worksheet consists of a cover page, table of contents, instructions for lecturers and students, models, information and key questions. The model is everything that is observed in the form of pictures, tables, equations, formulas, or laboratory activities and others.

Based on the model presented on the worksheet, key questions are made to find the concept by observing and investigating the given model, then given exercises that are direct applications of the concept to help students strengthen the concept.

\subsection{Develop Stage}

The development stage aims to produce teaching materials in the form of a revised worksheet based on input from the validator to obtain a device used in research. Aspects assessed by the validator are content validity, construct validity, linguistic components and graphic components.

The validity and practicality data were analyzed using the Kappa Cohen Formula (Warrens, 2015). The calculation method divides the number of values given by the validator with the maximum value (Aidha, 2013). From the results of the division, the validity category of the kappa moment interval is obtained. Interval categories based on kappa moments are presented in Table 1.

Table 1. Validity Category Based on Kappa Moment (Warrens, 2015)

\begin{tabular}{cc}
\hline Interval & Category \\
\hline $0.81-1.00$ & Very High \\
$0.61-0.80$ & High \\
$0.41-0.60$ & Moderate \\
$0.21-0.40$ & Low \\
$0.01-0.20$ & Very Low \\
0.00 & Invalid \\
\hline
\end{tabular}

The next data is the practicality of guided inquiry-based teaching materials in the form of a worksheet seen from products in the field concerning the practicality and implementation of the products developed. Practicality is the level of usability of the product by lecturers and students, namely by conducting teaching experiments using teaching materials that have been revised based on the assessment of the validator.

The level of practicality of the worksheet is determined from the questionnaire responses from lecturers and students. The lecturer filled out the questionnaire based on their assessment of the practicality of using teaching materials in teaching and filled it out by students based on their assessment of 

as Teaching Materials on Elements, Compounds and Periodic Table

using teaching materials. Lecturers and students fill out practicality questionnaires and then analyze them so that the level of practicality.

\section{Result and Discussion}

Based on research objectives and procedures, teaching materials were produced in guided inquiry-based worksheets for chemistry lectures as many as 104 pages. The results obtained were the validity of teaching materials by lecturers and the practicality of teaching materials by lecturers and students. The developed worksheet consists of a cover page, table of contents, instructions for lecturers and students, 12 (twelve) chemical activities/chemActivity consisting of models, information and key questions, then a glossary/index and a bibliography. The display of the cover page, chemActivity 8 and 12 of the worksheet are presented in the following Figure 1, 2, and 3.

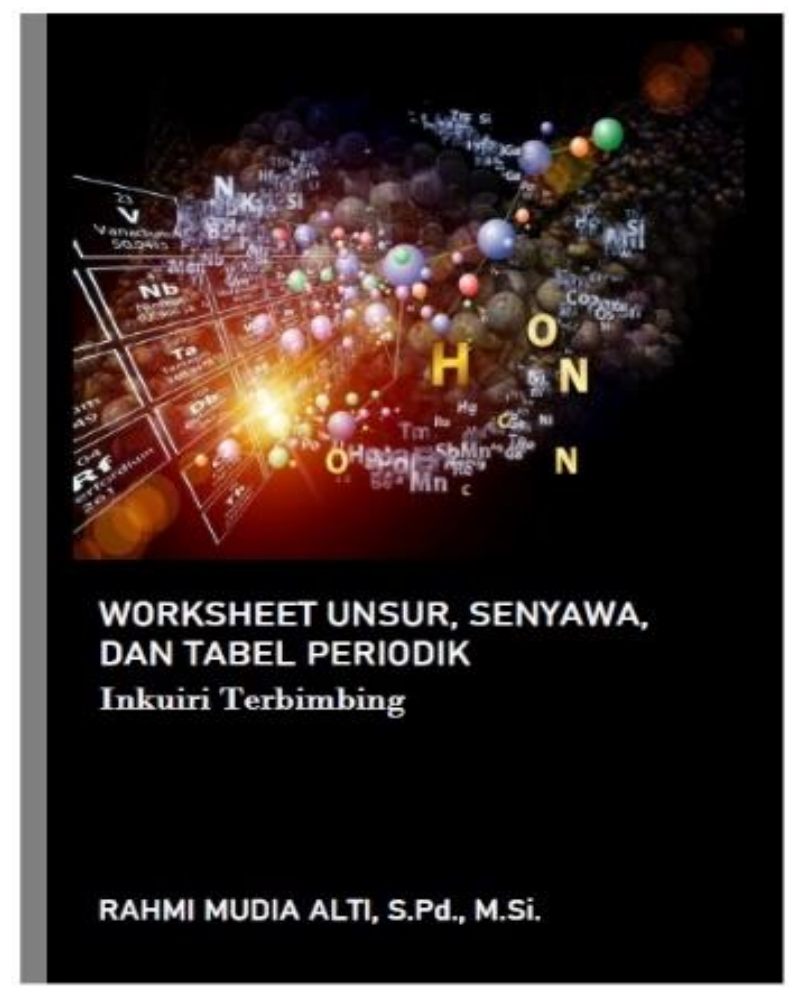

Figure 1. Worksheet Cover Page

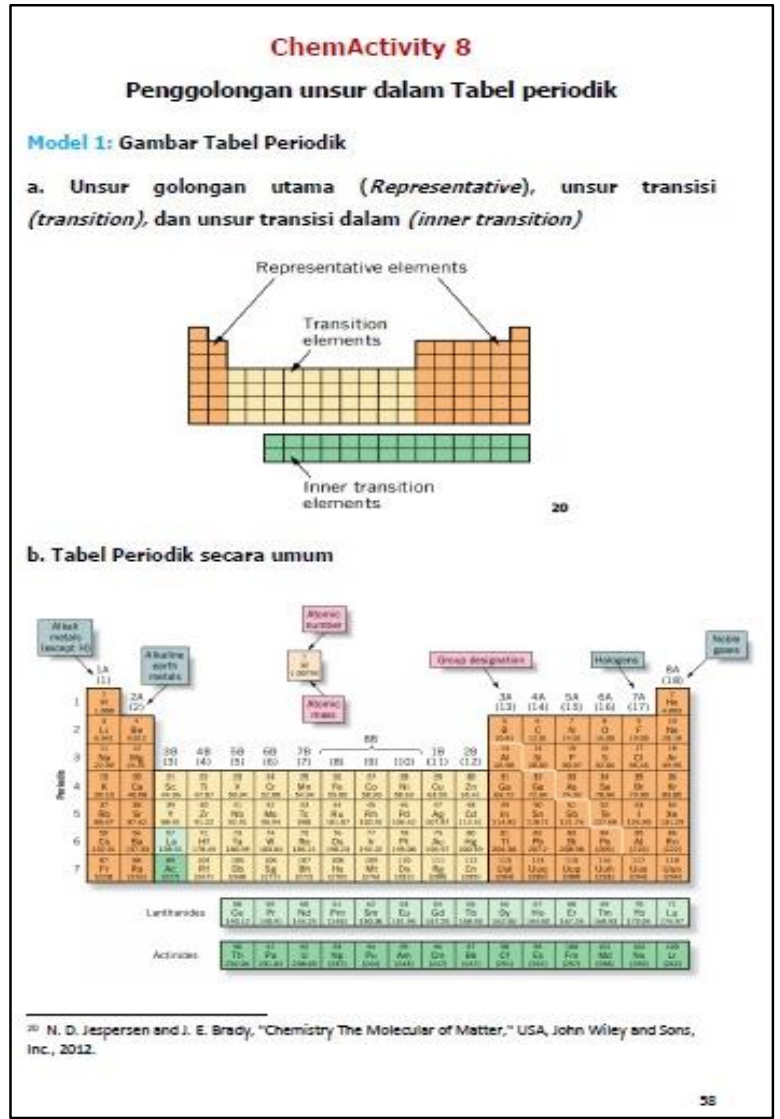

Figure 2. ChemActivity 8

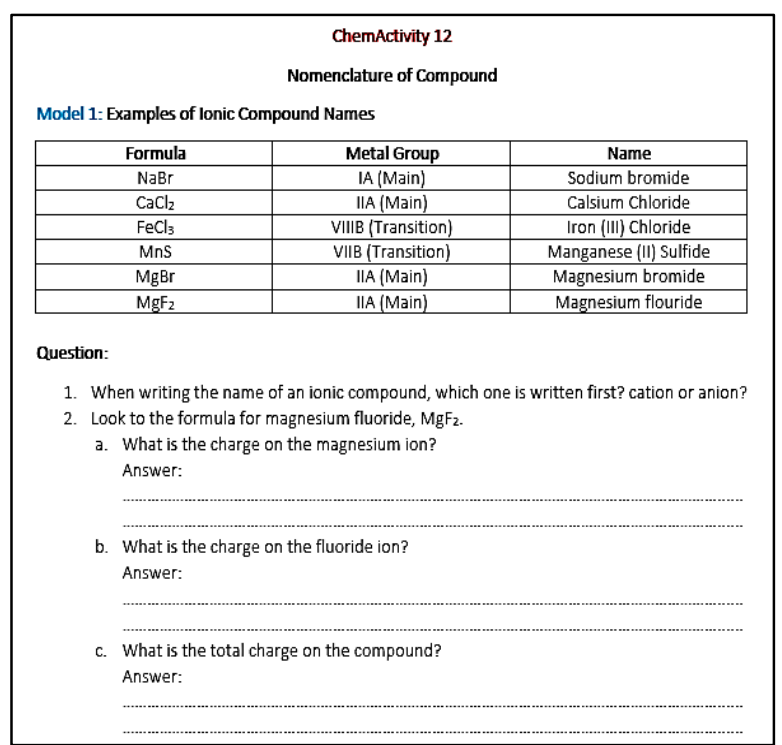

Figure 3. ChemActivity 12

The results of the teaching materials validation obtained data which presented in Table 2. 
Tabel 2. Assessment of the Teaching Materials Validity by Validators I, II and II

\begin{tabular}{clccc}
\hline No & Assessed Aspect & $\mathrm{k}(1)$ & $\mathrm{k}(\mathrm{II})$ & $\mathrm{k}(\mathrm{III}))$ \\
\hline 1 & $\begin{array}{l}\text { Content } \\
\text { feasibility }\end{array}$ & 0.96 & 1 & 0.78 \\
2 & $\begin{array}{l}\text { Construction } \\
\text { feasibility }\end{array}$ & 0.93 & 1 & 0.86 \\
3 & 0.93 & 0,93 & 0.73 \\
$\begin{array}{l}\text { Linguistic } \\
\text { component }\end{array}$ & 0.75 & 1 & 0.83 \\
$4 \begin{array}{l}\text { Graphic } \\
\text { component }\end{array}$ & 0.88 & 0.98 & 0.80 \\
\hline $\begin{array}{l}\text { Average value of kappa } \\
\text { moment }\end{array}$ & 0.88 & \\
\hline $\begin{array}{l}\text { Average value of } \\
\text { kappa moment from } \\
\text { all validator }\end{array}$ & \multicolumn{3}{c}{ Very High } \\
\hline Validity category & \multicolumn{3}{c}{} \\
\hline
\end{tabular}

Based on Table 2, the teaching materials developed have a very high validity value assessed from the average validity value of the three validators. According to Sugiyono (2017), several experts or experienced experts can carry out product validation to assess the weaknesses and strengths of the resulting product. In developing teaching materials, the experts in question are people who are considered to understand the intent and substance of providing teaching materials or can also be people who are professionals in their fields. The selection of these three experts is based on Sugiyono's opinion (2017) which states that experts (judgment experts) can be used at least three people to test the instrument's validity.

The feasibility of the content includes the suitability of the model presented in the worksheet with the lecture material and objectives, how the model can guide students in answering key questions, how key questions can lead to concept formation and how practice questions can strengthen concepts. In the feasibility of construction, the systematicity of teaching materials is assessed, the difficulty of key questions and the objectives to be achieved. The linguistic component assessed whether the language used is communicative, clear, and has no ambiguous meaning and the consistency of the use of symbols. Finally, in the graphic component, the clarity of images, letters, colors and the regularity of the layout used is assessed.

Indicators of the aspects assessed in the validity questionnaire are presented in Table 3.

Tabel 3. Indicators of the Validity of the Lecture's Response Questionnaire

\begin{tabular}{cl}
\hline No & Assessed Aspect \\
\hline 1 & $\begin{array}{l}\text { Suitability of model with the material being } \\
\text { taught }\end{array}$ \\
\hline 2 & $\begin{array}{l}\text { Suitability of the model to answer key } \\
\text { questions }\end{array}$ \\
\hline 3 & Suitability of key questions with indicators \\
\hline 4 & $\begin{array}{l}\text { Suitability of key questions to find the } \\
\text { concept }\end{array}$ \\
\hline 5 & $\begin{array}{l}\text { Benefits of key questions to conclude the } \\
\text { concept }\end{array}$ \\
\hline 6 & Systematics of teaching materials \\
\hline 7 & $\begin{array}{l}\text { Suitability based on the guided inquiry } \\
\text { learning cycle }\end{array}$ \\
\hline 8 & $\begin{array}{l}\text { Suitability of the model presented with the } \\
\text { indicators achieved }\end{array}$ \\
\hline 9 & $\begin{array}{l}\text { Suitability of the question with the } \\
\text { objectives to be achieved }\end{array}$ \\
\hline 10 & Key question systematics \\
\hline 11 & Information clarity \\
\hline 12 & Suitability with Indonesian language rules \\
\hline 13 & Consistent in the use of symbols \\
\hline 14 & Model clarity \\
\hline 15 & Use of fonts (type and size) \\
\hline 16 & Layout \\
\hline 17 & Color design on the model \\
\hline
\end{tabular}

Several parts of this teaching material that must be refined from the suggestions given by the validator, including adding image sources and a glossary, improving the writing of foreign terms, improving the units used, improving display brightness, correcting some typos and uniform writing. Based on input from the validators, revisions were made to the teaching materials to make them more perfect. Examples of suggestions from the validator can be seen in Figure 4.

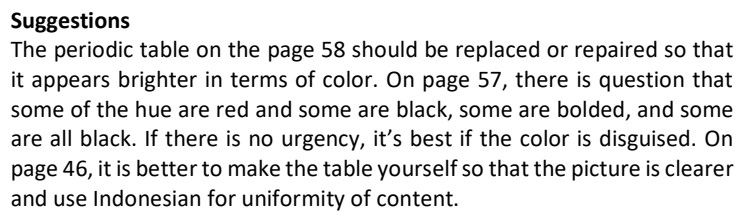

The periodic table on the page 58 should be replaced or repaired so that it appears brighter in terms of color. On page 57 , there is question that some of the hue are red and some are black, some are bolded, and some are all black. If there is no urgency, it's best if the color is disguised. On page 46 , it is better to make the table yourself so that the picture is clearer and use Indonesian for uniformity of content.

Figure 4. Example of Suggestion from Validator 

as Teaching Materials on Elements, Compounds and Periodic Table

The next data is the practicality data of teaching materials. Practical assessment by lecturers and students is presented in Table 4.

Tabel 4. Assessment of the Practicality of Teaching Materials by Lecturers and Students

\begin{tabular}{clc}
\hline No & Assessed Aspect & k \\
\hline 1 & $\begin{array}{l}\text { The practicality of teaching } \\
\text { materials from lecturer's }\end{array}$ & 0.72 \\
response questionnaire & \\
2 & $\begin{array}{l}\text { The practicality of teaching } \\
\text { materials from students' } \\
\text { response questionnaire }\end{array}$ & 0.78 \\
\hline Average value & 0.75 \\
\hline Practicality category & High \\
\hline
\end{tabular}

Based on the assessment data in Table 4, the level of practicality of the teaching materials in the form of a guided inquiry-based worksheet was obtained. This can be seen from the average acquisition of kappa moments from all aspects, which are assessed to reach 0.78 in the high practicality category.

The practicality of teaching materials in the form of guided inquiry-based worksheets for aspects of student understanding can be seen from the questionnaires filled out by students. The indicators in the questionnaire include the content of teaching materials, presentation in teaching materials, benefits of teaching materials and opportunities for teaching materials. These indicators are translated into several statements in the questionnaire. The indicators assessed in the lecturer and student response questionnaires are shown in Table 5 and Table 6.

\begin{tabular}{cl} 
Tabel 5. & $\begin{array}{l}\text { Practical } \\
\text { Indicators for Lecturers }\end{array}$ \\
\hline No & \multicolumn{1}{c}{ Indicator } \\
\hline 1 & $\begin{array}{l}\text { Clarity of instructions for using teaching } \\
\text { materials }\end{array}$ \\
2 & $\begin{array}{l}\text { Suitability of teaching materials with the } \\
\text { objectives to be achieved }\end{array}$ \\
3 & $\begin{array}{l}\text { Suitability of the model with the objectives } \\
\text { to be achieved }\end{array}$ \\
4 & $\begin{array}{l}\text { Key questions systematic } \\
\text { Benefits of practice in strengthening the }\end{array}$ \\
6 & $\begin{array}{l}\text { Concept } \\
\text { Benefits of using teaching materials for } \\
\text { lecturers }\end{array}$ \\
\hline
\end{tabular}

\begin{tabular}{cl}
\hline No & \multicolumn{1}{c}{ Indicator } \\
\hline 7 & $\begin{array}{l}\text { Benefits of teaching materials to improve } \\
\text { student learning activities }\end{array}$ \\
8 & $\begin{array}{l}\text { Benefits of using teaching materials to find } \\
\text { concepts }\end{array}$ \\
\hline
\end{tabular}

Tabel 6. Practical Response Questionnaire Indicators for Students

\begin{tabular}{|c|c|}
\hline No & Indicator \\
\hline 1 & $\begin{array}{l}\text { Clarity of instructions for using teaching } \\
\text { materials }\end{array}$ \\
\hline 2 & $\begin{array}{l}\text { Suitability of teaching materials with the } \\
\text { objectives to be achieved }\end{array}$ \\
\hline 3 & Key questions systematic \\
\hline 4 & Clarity of key questions \\
\hline 5 & $\begin{array}{l}\text { Benefits of practice in strengthening the } \\
\text { concept }\end{array}$ \\
\hline 6 & Suitability of the practice with the concept \\
\hline 7 & $\begin{array}{l}\text { Benefits of using teaching materials for } \\
\text { students }\end{array}$ \\
\hline 8 & $\begin{array}{l}\text { Benefits of teaching materials to improve } \\
\text { learning activities }\end{array}$ \\
\hline
\end{tabular}

The development of guided inquiry-based teaching materials also obtained good results in several previous studies. For example, the development of teaching materials in the form of a guided inquiry-based worksheet on acidbase materials obtains valid and practical product results (Priscylio et al., 2019). Furthermore, Sofiani et al. (2018) research shows that guided inquiry laboratory worksheets on temperature and heat materials have very good quality in content, linguistic and graphic aspects of questionnaire responses. In addition, the use of guided inquiry-based worksheets in learning also improves critical thinking skills (Prasetyowati \& Suyatno, 2016; Mulhayatiah et al., 2019; Putri \& Syafriani, 2020).

\section{Conclusion}

Based on the research that has been conducted, teaching materials are produced in the form of guided inquiry-based worksheets on elements, compounds and the periodic table for chemistry lectures with very high validity and high practicality categories. From the validity and practical results, the teaching materials in the form of a guided inquirybased worksheet can be applied to the chemistry lecture process. The weakness in 

as Teaching Materials on Elements, Compounds and Periodic Table

this research is the time management to be more effective in answering the questions in the worksheet.

The author suggests that the use of this worksheet is carried out in discussion groups. The teacher can intervene on process problems rather than content problems and provide suggestions to encourage deeper thinking. Further research can be developed for other materials and lectures.

\section{References}

Aidha, E. R. (2016). Pengembangan modul pembelajaran kimia pada materi pokok larutan elektrolit dan nonelektrolit berbasis inkuiri terbimbing (guided inquiry). Jurnal Sains dan Teknologi: Jurnal Keilmuan dan Aplikasi Teknologi Industri, 16(1), 70-77.

http://dx.doi.org/10.36275/stsp.v16i1. 57

Amalina, N. S., \& Wardani, S. (2018). Pembelajaran guided inquiry berbantuan lembar kerja siswa untuk meningkatkan hasil belajar siswa. JTK: Jurnal Tadris Kimiya, 3(1), 1. https://doi.org/10.15575/jtk.v3i1.2254

Arsanti, M. (2018). Pengembangan bahan ajar mata kuliah penulisan kreatif bermuatan nilai-nilai pendidikan karakter religius bagi mahasiswa Prodil PBSI, FKIP, Unissula. Jurnal Kredo, 1(2) https://doi.org/10.24176/kredo.v1i2.2 107

Aulia, E. V., Poedjiastoeti, S., \& Agustini, R. (2018). The effectiveness of guided inquiry-based learning material on students' science literacy skills. Journal of Physics, 012049. https://doi.org/10.1088/1742-

6596/947/1/012049

Depdiknas. (2008). Pengembangan bahan ajar. Jakarta: Direktorat Jenderal Manajemen Pendidikan.

Hanson, D. M. (2006). Instructor's guided to process-oriented guided-inquiry learning. New York: Pacific Crest.

Hartono, W., \& Noto, M. S. (2017). Pengembangan modul berbasis penemuan terbimbing untuk meningkatkan kemampuan matematis pada perkuliahan kalkulus integral. Jurnal Nasional Pendidikan Matematika), 1(2), 320-333. http://dx.doi.org/10.33603/jnpm.v1i2. 616

Kemdikbud. (2013). Pengembangan kurikulum 2013. Retrieved from http://staffnew.uny.ac.id: http://staffnew.uny.ac.id/upload/1982 08262015041003/pendidikan/pengem bangan\%20kurikulum\%202013.pdf

Mulhayatiah, D., Yuningsih, E. K., \& Zulfikar, R. M. (2019). Work and energy by guided inquiry worksheet: analysis of critical thinking skill in madrasah. Journal of Physics: Conference Series, 012072. Retrieved from https://iopscience.iop.org/article/10.1 088/1742-6596/1185/1/012115/pdf

Mustikasari, I., Sajidan, \& Karyanto, P. (2020). Analisis daya serap un siswa smp ditinjau dari standar nasional pendidikan. INKUIRI: Jurnal Pendidikan IPA, 42-45. https://doi.org/10.20961/inkuiri.v9i1.4 1380 
Ningsih, S. C. (2019). Pengembangan student worksheet berbahasa inggris dengan pendekatan problem based learning pada mata kuliah matematika diskrit. Journal of Mathematics Education IKIP Veteran Semarang, 65-74. https://doi.org/10.31331/medivesvete ran.v3i1.701

Pamenan, F. D., Harta, J., Listyarini, R. V., \& Wijayanti, L. W. (2019). Developing chemical equilibrium practicum module based on guided inquiry to explore students' abilities in designing experiments. Journal of Physics: Conf. Series, $\quad 1470 \quad 012097$. https://doi.org/10.24036/ekj.v3.i1.a21 7

Prasetyowati, E. N., \& Suyatno. (2016). Peningkatan penguasaan konsep dan keterampilan berpikir kritis siswa melalui implementasi model pembelajaran inkuiri pada materi pokok larutan penyangga. Jurnal Kimia dan Pendidikan Kimia (JKPK), 67-74. https://doi.org/10.20961/jkpk.v1i1.101 22

Priscylio, G., Andromeda, Mawardi, \& D Rochintaniawati. (2019). The development of guided inquiry worksheet on acid and base experiment for grade XI. Journal of Physics: Conference Series, 1280(3). IOP Publishing. Retrieved from https://iopscience.iop.org/article/10.1 088/1742-6596/1280/3/032017/pdf
Putri, S. R., \& Syafriani, S. (2020). Analysis development of guided inquiry based physics e-module to improve critical thinking ability of students high school. In Journal of Physics: Conference Series, 1481(1). IOP Publishing. Retrieved from Publishing. https://iopscience.iop.org/article/10.1 088/1742-6596/1481/1/012063/pdf

Sofiani, D., Sunarya, Y., \& Suryatna, A. (2018). Development of guided inquiry-based laboratory worksheet on topic of heat of combustion. In Journal of Physics: Conference Series, 983(1). IOP Publishing. Retrieved from https://iopscience.iop.org/article/10.1 088/1742-6596/983/1/012169/pdf

Sugiyono. (2017). Metode penelitian kuantitatif, kualitatif, dan R\&D. Bandung: Alfabeta.

Warrens, M. J. (2015). Five ways to look at Cohen's kappa. Journal of Psychology \& Psychotherapy, 5(4), 1. Retrieved from https://www.longdom.org/openaccess/five-ways-to-look-at-cohenskappa-2161-0487-1000197.pdf 